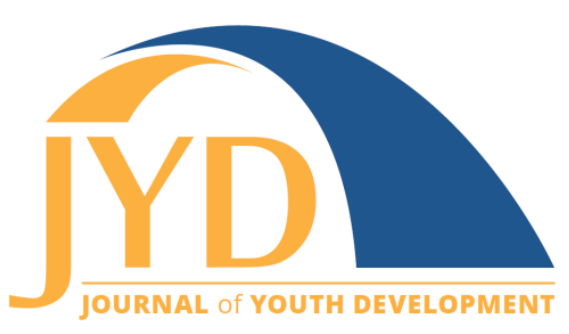

http://jyd. pitt. edu/ | Vol. 14 Issue 4 DOI 10.5195/jyd.2019.775 | ISSN 2325-4017 (online)

\title{
Becoming TED Speakers in School: Student Development Through Participation in TED-Ed Clubs
}

\author{
Melina Furman \\ CONICET, Buenos Aires and School of Education, Universidad de San Andrés \\ mfurman@udesa.edu.ar
}

Inés Taylor

School of Education, Universidad de San Andrés

itaylor@udesa.edu.ar

\section{Ariel Merpert}

Clubes TED-Ed - TEDXRiodelaPlata, Buenos Aires

hache@tedxriodelaplata.org

\section{Tobías Yatche}

Clubes TED-Ed - TEDXRiodelaPlata, Buenos Aires

tyatche@udesa.edu.ar

\section{Mariana Jacob}

Clubes TED-Ed - TEDxRiodelaPlata, Buenos Aires

jacobmarianamarcela@gmail.com

\section{Melania Ottaviano}

Clubes TED-Ed - TEDXRiodelaPlata, Buenos Aires

melania.ottaviano@gmail.com

\section{Celina Benegas}

Universidad de San Andrés

cbenegas@udesa.edu.ar

\section{Mariana Luzuriaga}

School of Education, Universidad de San Andrés mluzuriaga@udesa.edu.ar

(c) EY $_{\text {EY }}$ New articles in this journal are licensed under a Creative Commons Attribution 4.0 License. This journal is published by the University Library System, University of Pittsburgh and is cosponsored by the University of Pittsburgh Press. The Journal of Youth Development is the official peer-reviewed publication of the National Association of Extension 4-H Agents and the National AfterSchool Association. 


\section{Becoming TED Speakers in School}

\section{Abstract}

This case study explores adolescents' experiences of participating in TED-Ed Clubs in Buenos Aires, Argentina. TED-Ed Clubs is a school-based, extracurricular program in which 12- to 18-year-old youth develop and deliver a "TED-style" talk to their peers, teachers and parents. In particular, we explore changes in participants' self-development, communication skills and overall school experience. We conducted in-depth interviews with teachers, principals and focus groups of students from 8 representative schools. We find that students struggled considerably to establish what they had to say that was worth sharing with others, and-after a long process of self-reflection-ended up developing talks which were deeply personal in nature. Overcoming the challenge of finding and presenting a topic provided participating adolescents with a sense of accomplishment and pride. In addition, all participants reported changes in relationships with peers and adults, particularly with regards to discovering new sides of themselves and others through listening empathetically. Teachers also reported seeing their students through new lenses as they revealed new sides of themselves which had not been shown in other academic spaces. Overall, we find that the TED-Ed Clubs program appears to create new spaces in schools where adolescents can grow as individuals, and develop their own voice.

Key words: social development, organized activities (after-school, extracurricular), education/school, adolescence, self-image

\section{Introduction}

Twenty-first century skills such as critical thinking, problem-solving, communication, collaboration, creativity and innovation are considered fundamental to fostering lifelong learning in response to change, being able to ask and answer important questions, and for creating new knowledge and innovations that help build a better world (Trilling \& Fadel, 2009). Given their importance, developing $21^{\text {st }}$ century skills is a key educational goal for today's youth as it is critical for adolescents' future personal and professional success (Bedwell, Salas, \& Fiore, 2011).

However, despite most educational institutions proclaiming to subscribe to the goal of developing such skills in students, effectively doing so remains a challenge (Saavedra \& Opfer, 2012). One space within schools where communication and interpersonal skills might be developed is through extracurricular activities (Mahoney, Cairns, \& Farmer, 2003). Extracurricular activities contain several features which promote adolescent development, academic achievement and general well-being on multiple dimensions in ways that traditional school subjects may not (Eccles, Barber, Stone, \& Hunt, 2003; Vandell, Larson, Mahoney, \& Watts, 2015).

Recently, TED-Ed Clubs have emerged as a new extracurricular activity. TED-Ed Clubs are an initiative of the wider TED brand, most well-known for its online TED (technology, entertainment, design) Talks. Under the theme "Ideas Worth Spreading," TED Talks are given 


\section{Becoming TED Speakers in School}

by experts who present ideas in areas like science, business, culture, technology, art, and design (TED, 2017). When preparing their talks, TED speakers undergo a coaching process prior to presenting - a process which, while not yet studied academically, has anecdotally been classified as profoundly transformational (Anderson, 2017). Given the perceived value of the process of identifying an idea and communicating it to others, TED-Ed Clubs emerged as an extracurricular secondary school program which aims to engage students in the creation of their own TED Talks, while supporting them to develop their own passions, ideas and voices (TEDEd, 2018).

When participating in TED-Ed Clubs, students freely choose the topic of their talks, which might be considerably different from other similar activities, such as debate groups or public speaking clubs, where topics may be more limited. In this sense, TED-Ed Clubs give adolescents a direct way to share their personal views and develop their own "Idea Worth Spreading" through a guided process, as well as giving adults insights into what topics interest and inspire teenagers. The full TED-Ed Club process generally culminates in a school-based "TED-style" conference involving peers, teachers and parents, with videos of students' final TED-Ed Talk then shared online.

TED-Ed Clubs now exist in schools in over 100 countries (TED-Ed, 2018), but, despite this rapid expansion, little is known about TED-Ed Clubs' impact on adolescent development and wider school experiences (for example, in terms of their relationship with themselves, their peers, their academic ambitions or their teachers). Therefore, this paper seeks to understand the effect of participating in TED-Ed Clubs (specifically, the Argentine chapter of the program, known as "Clubes" hereafter) on students' development and school experience.

\section{TED-Ed Clubs in Argentina: Cultural Context}

Argentina is a developing country in South America, with education levels generally on par with those in wider Latin America (OECD, 2016). School teaching shows a strong encyclopaedic focus with limited attention given to the learning of $21^{\text {st }}$ century skills (Fiszbein \& Stanton, 2018; Furman, Luzuriaga, Taylor, Anauati, \& Podestá, 2018). In particular, activities explicitly focused on the development of communication skills such as debate or public speaking competitions exist, but are infrequent.

As a program, Clubes has existed in Argentina since 2014 in an adapted version of the original TED-Ed Club format. It has since expanded into all Argentine provinces, with over 370 


\section{Becoming TED Speakers in School}

registered schools reaching approximately 8500 students, via approximately 1000 teachers, supported by 20 coordinators who are education specialists (Clubes TED-Ed, 2018). The program is aimed at 12 - to 18 -year-old students and is free of charge for schools, which must select one of their teachers (from any curricular subject) to work with one or more groups of 20 students. Teachers are invited to an initial training session run by program coordinators. Here, they are given a step-by-step Clubes Pack, which outlines possible activities that encourage the development of student communication skills, interpersonal relationships and personal growth.

Clubes follow a series of 10 weekly 60 -minute lessons prior to a final school-based conference where peers, families, and teachers participate as audience members while Clubes speakers give their talks. Final talks are then expected to be filmed and uploaded to the program's web platform.

\section{Methods}

A qualitative case study approach was used, allowing us to analyze the experience of students, teachers and principals who took part in the program in depth.

\section{The Sample}

The sample was an intentional selection of eight schools, which were chosen in representation of the wider school population involved in Clubes (in terms of being public or private schools, serving populations from diverse socioeconomic contexts and geographic location from the autonomous city of Buenos Aires, and the province of Greater Buenos Aires, where most Clubes schools were located; see Table 1). Schools had between five and 80 (a full-year group) students participating in the program. Participants signed consent forms and were anonymized to ensure the protection of human subjects. 
Becoming TED Speakers in School

Table 1: Summary of School Characteristics

\begin{tabular}{|l|l|l|l|l|}
\hline School & $\begin{array}{l}\text { State or } \\
\text { Private }\end{array}$ & $\begin{array}{l}\text { Geographic } \\
\text { location }\end{array}$ & *Age (years) & $\begin{array}{l}\text { Brief description of school and student } \\
\text { population }\end{array}$ \\
\hline 1 & State & $\begin{array}{l}\text { Greater Buenos } \\
\text { Aires }\end{array}$ & 17 & $\begin{array}{l}\text { Small school, low socioeconomic status } \\
\text { population, semi-rural }\end{array}$ \\
\hline 2 & Private & $\begin{array}{l}\text { City of Buenos } \\
\text { Aires }\end{array}$ & 13 & $\begin{array}{l}\text { Bilingual, religious, high socioeconomic } \\
\text { status population }\end{array}$ \\
\hline 3 & Private & $\begin{array}{l}\text { Greater Buenos } \\
\text { Aires }\end{array}$ & $12-16$ & $\begin{array}{l}\text { Secular, suburban school, high } \\
\text { socioeconomic status population }\end{array}$ \\
\hline 4 & State & $\begin{array}{l}\text { Greater Buenos } \\
\text { Aires }\end{array}$ & 17 & $\begin{array}{l}\text { Large urban school, low socioeconomic } \\
\text { status population }\end{array}$ \\
\hline 5 & Private & $\begin{array}{l}\text { Greater Buenos } \\
\text { Aires }\end{array}$ & 14 & $\begin{array}{l}\text { Secular, suburban school, high } \\
\text { socioeconomic status population }\end{array}$ \\
\hline 6 & State & $\begin{array}{l}\text { City of Buenos } \\
\text { Aires }\end{array}$ & 13 & $\begin{array}{l}\text { Technical, large urban school, working } \\
\text { class socioeconomic status population }\end{array}$ \\
\hline 7 & Private & $\begin{array}{l}\text { City of Buenos } \\
\text { Aires }\end{array}$ & $15 \& 16$ & $\begin{array}{l}\text { Secular, large school, middle class } \\
\text { population }\end{array}$ \\
\hline 8 & Private & Aires & 15 & \begin{tabular}{l} 
Religious, middle class population \\
\hline
\end{tabular}
\end{tabular}

Note. *Age of student participants at program onset.

\section{Interview Method}

Three separate semi-structured interviews were undertaken in each school (24 interviews in total). First, a 30- to 45-minute focus group of three to five adolescents per school were interviewed to understand what they had learned, enjoyed, and found challenging when participating in Clubes. Students were selected by teachers who had overseen their participation, with the intention of showcasing the diversity of motivation and experiences that they had identified across the entire group, i.e. students were selected to represent a range of views and experiences, not just those who had particularly enjoyed or excelled during Clubes. Interviewees were encouraged to reflect on personal changes and developments, as well as perceived changes in their relationships with others.

Teachers who were involved in Clubes were also interviewed for 45 minutes, and asked to recount their experience of implementing the program. In addition, they were asked to reflect 


\section{Becoming TED Speakers in School}

on any changes, benefits or challenges associated with the program from a facilitator standpoint, as well as its impact on participating students. Teachers were also explicitly asked about how they guided students to develop their talks. Lastly, one principal from each of the eight schools was interviewed for about 20 minutes regarding their views on the overall impact of Clubes in their school and wider community.

\section{Data Analysis}

Interviews were transcribed verbatim and analyzed by two researchers concurrently using open coding (Creswell, 2008), coded initially according to opportunities and challenges in developing their talks, impact on adolescents and their development, and changes in their relationships with themselves and others. Subcodes from within each category were created inductively and shared between researchers, leading to a list of topics (for example, within the category of "challenges," subcodes included finding time, persistence, and choosing a topic).

Researchers then re-read and shared updated coding criteria. Validation strategies such as investigator triangulation and frequent peer debriefing between the co-authors were used to ensure the trustworthiness of the results and adherence to agreed criteria.

\section{Results}

\section{The Challenge-and Pride-of Having an Idea Worth Spreading}

In the first place, we found that for most participants the process of preparing their talk (finding a topic and then expanding on it) was a very challenging one. In many cases, students had to go through a long and sometimes arduous process of "finding something worth saying." In one student's words: "The process of developing the theme and the Talk was complex. In each meeting, we went over it all again, it was really difficult" (School 7).

In the end, many adolescents' personal interests served as a starting point from which to choose a topic. In fact, interviews suggested that students frequently chose topics that were deeply personal in nature and not strictly academic or particularly linked to school subjects. Instead, students chose topics which placed themselves at the center such as self-development, personal relationships or their views on education. 
Becoming TED Speakers in School

As teachers recognized that students struggled to find something to say, they viewed their role as pushing students to go from a place of "I have nothing interesting worth sharing" to standing on a stage in front of their peers and sharing their final talk. In this regard, one of the most prominent points made by the students was how they were nervous or afraid of preparing and, in particular, presenting their Clubes talks. Beyond the usual fear and stress of speaking in public (Westenberg et al., 2009) and taking into consideration that adolescence is a period associated with a general increase in stress (Nelson, Leibenluft, McClure, \& Pine, 2005), we believe that this was due to the fact that their topics were highly personal, leaving adolescents feeling vulnerable as they weren't "performing" or, as one principal stated, "not hiding behind a mask or a character, like in a play" (School 4).

Successfully presenting their final Clubes talk in front of their peers, teachers, and parents was thus a point of pride for adolescents and teachers, perhaps a result of overcoming the challenge. More than one adolescent mentioned giving their talk as one of the most important and impacting experiences in high school to date. To quote one female student:

Clubes is what most marked me in high school so far. Everyone congratulated me, students and teachers, and the principal, they

all congratulated me on how I gave the speech. It's a feeling that's hard to explain but I felt happy with myself, I felt useful. (School 1)

\section{Discovering Others by Revealing Yourself: Changes in Relationships}

A second theme that emerged from the interviews was the change in interpersonal relationships experienced between participating adolescents and their peers, teachers and even parents.

Showing, but mostly discovering, different sides of themselves and especially of their peers was highlighted by students. This may be partly due to the design of the program, which includes several activities aimed at fostering self-reflection, but perhaps this is also as a result of the vulnerability associated with sharing personal stories. This experience may also have been one of the first formal or structured opportunities for participants to examine and develop their own narratives, which is a part of identity construction during adolescence (Crocetti, 2017; McLean, 2005).

Constructing and presenting facets of their identity seems to have allowed adolescents to view and be viewed in a new light by their peers. All interviewees made some allusion to a change, 


\section{Becoming TED Speakers in School}

such as understanding their peers in new and more profound ways. Students also discovered previously unknown aspects of their peers' lives. This could go from "small" discoveries of their peers' interests and hobbies, to much larger aspects, such as in one striking example where a student learned that their peer was a parent. There was also a strong indication of students discovering appreciation for the individuality of each person's experiences, and approaching each person's uniqueness from a nonjudgmental standpoint. As one student shared:

I remember a girl who was also in Clubes, and her talk was about stereotypes. Because, for example, she is a girl and she liked to dress like a boy, then everyone judged her, criticized her. Her family too. Her mom didn't like that she dressed like that. But she does. And she taught me that people shouldn't be stereotyped and that they should not be judged for how they want to dress or be. And I didn't even imagine that there was a whole story behind how she dressed. (School 4)

Adolescence is a particular period of development where peers are highly influential in promoting well-being by providing a sense of belonging and acceptance (Guyer, Caouette, Lee, \& Ruiz, 2014). Clubes seems to be able to provide a safe space for participants to explore their identity with peers in a guided way, reflecting on their own identity and how to communicate their views and experiences.

As well as amongst peers, student interviews suggested that the relationships adolescents had with the adults in their lives transformed. Students frequently mentioned their parents in interviews, generally in positive and grateful terms, and indicated that they viewed their parents through a new lens after participating in Clubes-less as just "their parents" and more as complex adults with their own histories and experiences. This was evident in the way that several students spoke about how their parents were inspirations and examples on whom they based their talk, and suggested that they valued and admired sacrifices or choices made by their parents, and that they viewed these sacrifices or choices in multifaceted, complex ways. As a different student explained:

[My mom] couldn't study when she was a girl because she had a health problem, and today she is studying thanks to a [government welfare] plan called "Ellas hacen." She had a second chance to study, and I related it to the opportunities we have in life, so that's why I chose this topic. But mainly my whole Talk was about my mother and her studies. (School 1) 
In some cases this experience of standing before their parents during the final conference was very profound. This is perhaps unsurprising, as adolescence is a time typically associated with a shift in parental relationships (Greenfield, Keller, Fuligni, \& Maynard, 2003; Rice \& Mulkeen, 1995), and although peers play an increasingly important role in adolescents' lives, parents were previously the main listeners and audience of children's narrative identity storytelling (Pasupathi \& Weeks, 2010). For example, one student spoke about how he used his TED-Ed Talk to share his coming to terms with his homosexuality publicly. As his testimony shows, this was a very emotionally charged moment, particularly in terms of feeling listened to by his mother, whom he described not being understood by previously despite talking to her. As he describes, his talk was clearly a moving experience for both him and his mother:

My family was also there, and my mom, I had come out to her a while ago. I think I showed her things from my point of view, something I just couldn't do in a conversation. Just by talking I couldn't reach her, she didn't understand me, but with this talk I talked about that and several other things. I noticed her as she listened to me, it was like a link that we had broken that came back. Because she was the first one who approached me crying to hug me when I came down. She told me "I heard you, forgive me son, forgive me." I get goosebumps when I remember it. (School 3)

Lastly, teachers and principals also spoke of seeing their students in new ways. Clubes provided a way for teachers to rediscover their students, and created a chance of a more personal relationship. As one teacher reflected, this allowed them to open up more honest conversations and foster deeper relationships:

What I enjoyed the most was being able to see the kids in an authentic way, giving them the freedom to say what they wanted, what they thought, without censorship. I saw that they always said what they were thinking. (School 7)

\section{Listening and Being Heard: Developing Communication Skills}

In terms of communication skills, in the first place (as expected) students spoke about improving their public speaking skills. Many students mentioned that they felt their capacity to stand on a stage, speak clearly and be understood had improved as a result of the Clubes process. However, this finding was far less prominent than the emergence of a different kind of 


\section{Becoming TED Speakers in School}

communication skill, namely: listening. Listening and being listened to came up time and time again, explicitly and implicitly, over the course of the interviews. This form of being seen and heard, really listened to came out in several dimensions. In particular, there seemed to be a distinct difference between the type of listening that occurs in "normal" lessons versus the attentive focus and active listening seen during their final talks or during the program meetings.

In this sense, the creation of a space to truly be listened to (a key part of effective communication (Wolvin \& Coakley, 2000) seems to be innovative and deeply valued by all participants. This listening, in turn, was fundamental as a tool towards changing relationships (as discussed earlier), and allowing each person to get to know others better and appreciate different points of view. In the words of one student:

I think you basically learn to listen. Obviously you learn to listen because you have to, it forces you to listen [laughs]. Because it's each person's story, the process of each one, of us or of the group, and there comes a point where without realizing you are listening to the other, you are learning [... ] you learn to see things differently, from the point of view of who was talking to you. (School 3)

Adolescents also frequently associated this real listening with being less judgmental. Considering that adolescence might be a particularly stress-sensitive time in life (Andersen \& Teicher, 2008) where individuals are particularly vulnerable to the opinions and judgement of others (Guyer et al., 2014), this finding suggests a striking departure from that prerogative. Students linked this lack of judgement with taking the time to understand and listen to others, such as is shown in these two examples:

I believe that my classmates learned to listen. I also learned to listen to others. And that is very different because you always . . . like you judge the other person, you see a person and you say "that's the way it is, that's the way it is". . . and you imagine a character. And then you listen to their talk and it's something else, you can't imagine what's happening to them. Then you also learn not to judge other people. (School 4)

I learned to listen without judging so much. But as I first have to listen to the whole talk [. . .]. That's where it happens, because you couldn't interrupt the conversation. Nothing, you had to really 
let it finish. Without judging . . . Learning to close your mouth and pay attention. (School 8)

Understanding that listening can in turn generate deeper dialogues and discussions, and engender empathy (Swartz, Costa, Beyer, Reagan, \& Kallick, 2008; Wolvin \& Coakley, 2000), suggests this aspect of Clubes deserves special attention. If we wish to educate young adults who are empathetic, understanding and nonjudgmental, with substantive interpersonal skills and the belief that they have ideas and a voice worth sharing with others, then Clubes appears to offer promising ways of developing this mindset.

\section{Discussion}

We found that Clubes brought about several positive changes for participating adolescents. We saw increases in adolescents' reported self-knowledge, empathy, and communication skills, which mirrored the transformational effects reported in "real" TED speakers (Anderson, 2017).

In addition, our data showed that Clubes gives schools a way of making the transformation of adult-child relationships and identity-building processes which occur during adolescence (Pasupathi \& Weeks, 2010) visible by encouraging students to move away from being children and towards young adults with voices, opinions and their own narratives (McLean, 2005). This repositioning of students was, in turn, a key factor in driving new relationships with peers and adults. Establishing positive interpersonal relationships is a key skill for both school and life more generally (Bedwell et al., 2011), as well as incidental in students well-being at school. This implies that schools can benefit from providing more spaces where students can explore their ideas, concerns, and interests in the company of others, and reflect on their identity and relationships more generally.

Therefore, preparing adolescents to give their TED-Ed Talk might give students a fuller voice, which in turn has been associated with increases in agency, belonging, and competence (Mahoney et al., 2009; Mitra, 2004). It may also develop crucial $21^{\text {st }}$ century skills such as creativity, resilience and critical thinking (Bedwell et al., 2011). Exploring and identifying one's passions and identity is also a valuable endeavour for teenagers as they approach the end of compulsory formal schooling (Crocetti, 2017; Pasupathi \& Weeks, 2010). Lastly, TED-Ed Clubs provide an authentic way to enhance communication skills and develop "presentation literacy," i.e. presenting ideas effectively to wider audiences in different formats (Anderson, 2017). 


\section{Becoming TED Speakers in School}

This study is only an initial exploration of the impact of participating in Clubes. In fact, we only selected a small sample of schools in Argentina that had managed to finish the program, which implies there may be many more aspects of participation than is currently captured, particularly when considering that Clubes now exists in nearly 400 schools. It would also be interesting to understand impacts in terms other than student and teacher self-perceptions, perhaps expanding to include the views of parents or measure changes in particular skill sets such as public speaking. Despite this, we argue that the findings from this study open further questions and insights into the value of providing guidance for self-reflection and identity construction within more formal school settings.

In this sense, we suggest that TED-Ed Clubs provide a space in which adolescents can be proud of themselves, not just as "academics" but rather as individuals. This was also a space in which character or maybe a "sense of self" was valued above other things, rather than traditional metrics of adolescent or academic success. We therefore found that TED-Ed Clubs appear to have the potential for developing $21^{\text {st }}$ century skills and character development (Berkowitz \& Bier, 2007), particularly through reflecting on the process of finding one's voice and overcoming a personal challenge. This was regardless of whether the program was carried out with all or just a few members of the school-year group or community, demonstrating a high potential for scalability.

As schools rise to the challenge of preparing adolescents with the skills they need to move into the next stages of their lives, our study shows that activities which encourage adolescents to connect with others empathetically and discover themselves more profoundly have to become a more fundamental component of the school experience.

\section{References:}

Andersen, S. L., \& Teicher, M. H. (2008). Stress, sensitive periods and maturational events in adolescent depression. Trends in Neurosciences, 31(4), 183-191.

Anderson, C. (2017, January 5). The skill you need now: presentation literacy. Ideas.TED.com. Retrieved from: https://ideas.ted.com/the-skill-you-need-now-presentation-literacy/

Bedwell, W. L., Salas, E., \& Fiore, S. M. (2011). Developing the $21^{\text {st }}$ Century (and beyond) workforce: $A$ review of interpersonal skills and measurement strategies. In NRC Workshop on Assessing $21^{\text {st }}$ Century Skills, Irvine, CA. Retrieved from: http://texasccrsm.org/sites/default/files/NRC__21st_Century_Skills_and_Competencies.pdf 
Becoming TED Speakers in School

Berkowitz, M. W., \& Bier, M. C. (2007). What works in character education. Journal of Research in Character Education, 5(1), 29-49. Gale Document Number: A234229594

Clubes TED-Ed. (2018). Homepage. Retrieved from: http://Clubes.tedxriodelaplata.org/

Creswell, J. W. (2008). Educational research: Planning, conducting, and evaluating quantitative and qualitative research ( $3^{\text {rd }}$ ed.). Upper Saddle River, NJ: Pearson Education.

Crocetti, E. (2017). Identity formation in adolescence: The dynamic of forming and consolidating identity commitments. Child Development Perspectives, 11(2), 145-150.

Eccles, J. S., Barber, B. L., Stone, M., \& Hunt, J. (2003). Extracurricular activities and adolescent development. Journal of Social Issues, 59(4), 865-889. doi:10.1046/j.0022-4537.2003.00095.x

Fiszbein, A., \& Stanton, S. (2018). The future of education in Latin America and the Caribbean: Possibilities for United States investment and engagement (Inter-America Dialogue Report). Retrieved March 2019 from: https://bit.ly/2uu65u9

Furman, M., Luzuriaga, M., Taylor, I., Anauati, M. V. \& Podestá, M. (2018). Abriendo la "caja negra" del aula de ciencias: un estudio sobre la relación entre las prácticas de enseñanza sobre el cuerpo humano y las capacidades de pensamiento que se promueven en los alumnos de séptimo grado. [Opening the "black box" of the science classroom: a study on the relationship between teaching practices and thinking skills promoted in students]. Enseñanza de las Ciencias, 36(2), 81-103

Greenfield, P. M., Keller, H., Fuligni, A., \& Maynard, A. (2003). Cultural pathways through universal development. Annual review of psychology, 54(1), 461-490.

doi:10.1146/annurev.psych.54.101601.145221

Guyer, A. E., Caouette, J. D., Lee, C. C., \& Ruiz, S. K. (2014). Will they like me? Adolescents' emotional responses to peer evaluation. International journal of behavioral development, 38(2), 155-163. doi:10.1177/0165025413515627

Mahoney, J. L., Cairns, B. D., \& Farmer, T. W. (2003). Promoting interpersonal competence and educational success through extracurricular activity participation. Journal of Educational Psychology, 95(2), 409. doi:10.1037/0022-0663.95.2.409

McLean, K. C. (2005). Late adolescent identity development: narrative meaning making and memory telling. Developmental psychology, 41(4), 683. doi:10.1037/0012-1649.41.4.683

Mitra, D. L. (2004). The significance of students: Can increasing "student voice" in schools lead to gains in youth development? Teachers College Record, 106(4), 651-688. doi:10.1111/j.14679620.2004.00354.x

Nelson, E. E., Leibenluft, E., McClure, E. B., \& Pine, D. S. (2005). The social re-orientation of adolescence: a neuroscience perspective on the process and its relation to psychopathology. Psychological medicine, 35(2), 163-174.

OECD. (2016). PISA 2015 Results (Volume 1): Excellence and Equity in Education. Paris: OECD Publishing. 
Journal of Youth Development | http://jyd.pitt.edu/ | Vol. 14 Issue 4 DOI 10.5195/jyd.2019.775

Becoming TED Speakers in School

Pasupathi, M., \& Weeks, T. L. (2010). Integrating self and experience in narrative as a route to adolescent identity construction. In T. Habermas (Ed.), New Directions for Child and Adolescent Development, special issue: The development of autobiographical reasoning in adolescence and beyond, 131, 31-43. doi:10.1002/cd.287

Rice, K. G., \& Mulkeen, P. (1995). Relationships with parents and peers. Journal of Adolescent Research, 10(3), 338-357. doi:10.1177/0743554895103003

Saavedra, A. R., \& Opfer, V. D. (2012). Learning $21^{\text {st }}$-century skills requires $21^{\text {st }}$-century teaching. Phi Delta Kappan, 94(2), 8-13. doi:10.1177/003172171209400203

Swartz, R., Costa, A., Beyer, B., Reagan, R., \& Kallick, B. (2008). El aprendizaje basado en el pensamiento [Learning based on thinking]. España: SM.

TED. (2017, May). TED Talks: Programs \& Initiatives. Retrieved from: https://www.ted.com/about/programs-initiatives/ted-talks

TED-Ed. (2018). Start a TED-Ed Club at your school. Retrieved from: https://ed.ted.com/Clubs

Trilling, B., \& Fadel, C. (2009). 21 st century skills: Learning for life in our times. Hoboken, NJ: John Wiley \& Sons.

Vandell, D. L., Larson, R. W., Mahoney, J. L., \& Watts, T. W. (2015). Children's organized activities. In R. M. Lerner (Series Ed.), Ecological Settings and Processes: Vol. 4. Handbook of child psychology and developmental science (7 $7^{\text {th }}$ ed., pp. 305-334). Hoboken, NJ: John Wiley. doi:10.1002/9781118963418.childpsy408

Westenberg, P. M., Bokhorst, C. L., Miers, A. C., Sumter, S. R., Kallen, V. L., van Pelt, J., \& Blöte, A. W. (2009). A prepared speech in front of a pre-recorded audience: Subjective, physiological, and neuroendocrine responses to the Leiden Public Speaking Task. Biological Psychology, 82(2), 116124. doi:10.1016/j.biopsycho.2009.06.005

Wolvin, A. D., \& Coakley, C. G. (2000). Listening Education in the $21^{\text {st }}$ Century. International Journal of Listening, 14(1), 143-152. doi:10.1080/10904018.2000.10499040 